\title{
Effect of the electrolipophoresis in the lipodystrophy treatment and its influence on lipid profile
}

\author{
Thais Moreira de Oliveira', Priscila Hellen Martinez Blanco ${ }^{2}$, Priscila Manchini ${ }^{3}$, Nawhale Delbone ${ }^{4}$
}

\begin{abstract}
Introduction: The excess of body adiposity and the hormonal action can lead to the accumulation of adipose tissue in certain parts of the body. The electrolipophoresis is a technique used to treat localized fat, by applying low frequency electrical currents that act directly on the adipocytes and lipids accumulated subcutaneously or epicutaneously. This electrical stimulation causes physiological modifications in the adipocyte, among them the increase in blood flow and cellular metabolism leading to lipolysis. Objective: This study aimed to prove, through the measurement of triglycerides in the blood, which is the most effective method of electrolipophoresis practical application in the promoted lipolysis. Methods: The old female patients aged from 49 to 62 underwent evaluation that measured the body mass index (BMI); perimetry performed with the use of measuring tape of the waist and abdomen region and the realization of abdominal (vertical) skinfold measurement with the use of adipometer. After the evaluation, the volunteers were divided into two groups in which one of them received subcutaneous application of electrolipophoresis equipment (needles) and the other one received epicutaneous electrolipophoresis application (plates). They were positioned and oriented about the procedure and received the practical application of electrolipophoresis (DGM equipment) twice a week for ten sessions of 60 minutes each. The dosage of triglycerides was performed in the first and last session. Results: There was a reduction in all evaluations performed, and a subcutaneous application shows more effective in the treatment of localized fat. Conclusion: With these findings was observed a reduction in abdominal measurement and decreased of triglycerides in the blood thus showing that treatment using plates or electrodes is effective in localized lipodystrophy. Despite the significant reduction of localized adiposity, further studies with more participants and sessions are needed to make this treatment, widely used in clinical practice of Dermato-Functional Physiotherapy, most reliable.
\end{abstract}

Keywords: abdominal fat, electrolipophoresis, lipolysis.

\section{INTRODUCTION}

The aesthetic word is originated from the Greek (aisthesis, aistheton-feeling, sensitive), which has the meaning of sensation, sensitivity and perception through the senses or sensory-sensitive knowledge. ${ }^{(1,2)}$ The concern about a healthy and beautiful body has been affecting all the different genders, age groups and social classes. ${ }^{(3)}$ The importance being given to the look, appearance, body, beauty and aesthetic is noticeable nowadays, which the cult of the beautiful body has become increasingly common, ${ }^{(4)}$ and has been increasing in urban and industrialized societies as a transformation and improvement object. ${ }^{(5)}$

Given this concern with beauty, body image becomes a topic of interest in society, being so strong that leads people to become too concerned with themselves. ${ }^{(4,6)}$ Therefore, people look for both facial and bodily aesthetic treatment, to increase their self-esteem, feeling more happy and fulfilled with their appearance. With this high demand, professionals in the aesthetics area seek to stay updated with the issues related to this, in order that the aesthetic increase even further the range of its products, devices and treatments. ${ }^{(7)}$

The stored fat is the greatest corporal source of potential energy. ${ }^{(8)}$ When the intake of foods with high calorie content is excessively, it is stored as fat, usually responsible for the formation of aesthetic dysfunction known as localized fat or localized lipodystrophy. ${ }^{(9,10)}$ The high rate of body fat and hormone action can lead to accumulation of fat tissue in certain parts of the body.

The main cell energy supplier are adipocytes, but in order to the stored body fat is available as energy to the body is required to occur lipolysis, i.e., the metabolism of fat stored in adipocytes into fatty acids and glycerol, that when metabolised span the cell membrane of the adipocyte, entering the blood capillary circulation, in the bloodstream they bind to serum

Corresponding Author: Thais Moreira de Oliveira. Rua Tiradentes, 369. CEP: 87200-105 Cianorte (Paraná), Brazil. E-mail: thamoreira_17@hotmail.com

1 Student of the Biomedicine course, Unicesumar, Cianorte (PR), Brazil

Full list of author information is available at the end of the article.

Financial support: The UniCesumar University provided the cosmetic clinic, along with the instruments and apparatus necessary for the procedure and research development.

Submission date 23 May 2016; Acceptance date 12 August 2016; Publication online date 26 August 2016 
albumin (carrier protein) and are transported to the cells that use it as an energetic substrate. ${ }^{(9,11)}$

The electrolipophoresis is a technique that acts directly on the lipolytic action, which aims at treating the accumulation of localized fatty acids. ${ }^{(12)}$ It involves the application of several pairs of long and thin needles connected to a low-frequency bidirectional current through specific waves, which operates in adipocytes and accumulated lipids to produce lysis of these structures and to promote their elimination. ${ }^{(11,13)}$

The physiological effects provided by the use of electrolipophoresis in cases of localized lipodystrophy are: the Joule effect, which consists in heating of the tissue due to the movement of electric current and it is sufficient to contribute to a vasodilation with increase in local blood flow, so, it stimulates the cellular metabolism, facilitating the burning of calories and improving muscle trophism; the electrolytic effect, which is the increase in ion motion in the tissue generated by the electric field; the circulatory effect, which promotes lymphatic and blood drainage, causing an improvement in the quality and appearance of the skin; and neurohormonal effects, which produces an artificial stimulation of the sympathetic nervous system and occurs as a result of the release of catecholamines, leading to lipolysis of the region that is receiving electrical stimulation of the device. ${ }^{(11)}$

The main aesthetic indications for the use of electrolipophoresis equipment are the clinical conditions such as lipodystrophy ${ }^{(11)}$ and act by stimulation area located between the electrodes or between the needles connected to equipment poles. During the clinical choice of this device the therapist can choose between two application techniques: epicutaneous application (technique which uses silicon electrodes or conductive carbon), and subcutaneous application (applied technique with stainless steel needles). ${ }^{(11,12)}$

According to researches, ${ }^{(11)}$ electrolipophoresis device allows treatment with various waveforms, and this procedure must be respected during therapeutic sessions to ensure the therapeutic results offered by it. Therefore, during all sessions is used the acute rectangular current to decrease local impedance, acting at the level of epidermis; the rectangular current stimulates the dermis promoting vasodilation and resulting in tissue oxygenation and elimination of toxins; the acute trapezoid current aims to act in hypodermis performing hypertrophy of adipose tissue, i.e., this current is responsible for the lipolysis process; finally, the wide trapezoid current which promotes improvement of the nutrition of muscle tissue benefiting their trophism and tissue drainage of the treated region.

Therefore, this study aims to compare the forms of practical application regarding the lipolysis effect provided by the equipment analyzing the triglyceride blood dosage of the women subjected to corporal sessions electrolipophoresis, to reduce abdominal fat and detect the most effective way for this aesthetic dysfunction as well as analyze the influence of the equipment on the lipid profile of women undergoing treatment.

\section{METHODS}

\section{RESEARCH CHARACTERIZATIONS}

This study is a comparative and quantitative research that was conducted after submission to the ethics committee of the University Center of Maringá. After approval (717.336), this research began to be realized in the aesthetic clinic of the University Center of Maringá-Paraná (UNICESUMAR), upon prior approval by the course coordinator.

\section{POPULATION}

The study population was composed of four female volunteers aged from 49 to 62, from Maringá - Paraná, Brazil.

The inclusion criteria used in this study were: Female, aged from 49 to 62 , to have dense fat in the abdominal region and does not be in physical, aesthetic or nutritional treatment. The exclusion criteria of the study were: men and women who practice physical activity; intolerance or fear of needles; performing aesthetic treatments in the abdomen; the use of cosmetics in the abdominal region; pregnant women; cardiac patients with pacemakers or metal implants in the area; heart disease; deep vein thrombosis; cancer or tumors; hypertension; hypoglycemia; diabetes; hypothyroidism; use of medications such as corticosteroids, anticoagulants or skin changes, such as dermatitis or skin diseases, wounds, inflammation and rashes, as they may present irritation to the electric current.

Before the execution of the research, the volunteers signed the Free, prior and informed consent, that contained the necessary information about the development and purpose of this research, as well as that this research is a scientific academic work and the volunteers would be care by the researcher with the supervision of the guiding teacher in the Aesthetics Clinic of the Unicesumar and blood chemistries were done in the laboratory of clinical analysis of São Camilo, Rua Santos Dumont, 3430 - zone 1, Maringá-PR, which values were defrayed by the researcher.

\section{INSTRUMENTS}

To the execution of this research were used: body aesthetic evaluation form; camera; adipometer; measuring tape; digital balance; Electrolipophoresis equipment (dgm brand); elastic bandages; disposable needles from 0.25 to $0.30 \mathrm{~mm}$ in diameter and 3 to $4 \mathrm{~cm}$ in length; carbon rubber electrodes; neutral conductor gel; alcohol 70; exfoliating body; spectrophotometer (read from 490 to $520 \mathrm{~nm}$ ); a waterbath or thermostatic bath regulated at $37^{\circ} \mathrm{C}$; tubes; pipettes; stopwatch. 


\section{PROCEDURES AND RESEARCH DEVELOPMENT}

Because it is a study involving humans, initially the project was referred for evaluation of the Research Ethics Committee (CEP). The study was based on the Aesthetics Clinic of Unicesumar- University Center of Maringá.

The first procedure performed was the body aesthetic evaluation of the volunteers. Along with the photographic record with the camera (Olympus) using a blue background to facilitate the visualization of abdominal adiposity, were made the body evaluation form containing personal data of each volunteer, personal characteristics, anthropometric data (height and weight - performed barefoot and bathing suit, using a digital scale - both in orthostatic position), the body mass index (BMI) in which is divided the weight by height squared (if the BMI value is less than 20 is reported as below the weight, between 20 and 25 is rated as ideal weight and above 25 is overweight), the perimetry performed using measuring tape in waist region and abdomen, which is measured as follows: $5 \mathrm{~cm}$ infraumbilical and $5 \mathrm{~cm}$ and $10 \mathrm{~cm}$ supraumbilical, the measurement of abdominal (vertical) skinfold with the use of adipometer and the undressed patient in standing position. Two evaluations were conducted, being an assessment before the first session and re-evaluation after the last session of each volunteer, always by the same evaluator to avoid misinterpretations or post-results influences.

After the evaluation, the volunteers were divided into two groups in which one of them received subcutaneous application of electrolipophoresis equipment (needles) and the other one received epicutaneous electrolipophoresis application (plates). They were positioned and oriented about the procedure and received the practical application of electrolipophoresis (DGM equipment) twice a week for ten sessions of 60 minutes each. The dosage of triglycerides was performed in the first and last session.

The disposable needles are used in systemic acupuncture and made of stainless steel and sterilized by ethylene oxide. The size of them was from 0.25 to $0.30 \mathrm{~mm}$ in diameter and 3 to $4 \mathrm{~cm}$ in length and the number of needles varied according to the size of the application region, respecting a distance of $5 \mathrm{~cm}$ between each needle. For the introduction of needles, crimping the skin and the subcutaneous tissue was needed, with more firmly to slide the needle using the "guide tube". The technique involves press the guide tube on the skin and gives a quick tap on the top of the needle, inserting it perpendicularly to the skin surface. It is indicated to tilt the needle into the subcutaneous tissue, introducing horizontally, thereby seek to provide the interaction of the current with a higher adipose tissue area. After the application, the needles were attached to the connector cables of the claw type.

The electrodes used were silicon-carbon, non-invasive therapeutic procedure and great application in aesthetic treatments. The electrodes were coupled with the use of a neutral gel, to avoid burns, at a distance of $5 \mathrm{~cm}$ between them, alternating positive and negative, and involved two fastening strips. Throughout the session the researchers were with the volunteers and adjusting the intensity according to skin sensitivity of each subject.

After performing the aesthetic procedure, the dosage of triglycerides in the blood of patients was made at the end of the first and tenth session for comparative data on fat metabolism and the application methods of the electrolipophoresis practice.

To perform the test procedure first 3 test tubes must identify as "White", "Test" and "Standard". Pipette $10 \mu \mathrm{L}$ of the sample into "Test", 10 $\mu \mathrm{L}$ of standard (1) into "Standard" and $1000 \mu \mathrm{L}$ of the color reagent (2) into "White", "Test" e "Standard". Homogenize and incubate the tubes at $37^{\circ} \mathrm{C}$ for $10 \mathrm{~min}$. The level of the water bath should be higher than the level of the reactants in the tubes. Read the absorbance of "Standard" and "Test" tubes, resetting the device with the "White" tube in 505nm or filter-green (490-520nm). The color is stable for 1 hour.

\section{ANALYSIS OF RESULTS}

After collecting the relevant data to the survey, these were entered into spreadsheets in Microsoft Office 2010 software, and statistically analyzed with the Statistica Software 8.0 to compare the frequency, percentage and statistical analysis of the initial and final evaluations. The test used for comparisons was the Wilcoxon paired test considering a significance level of $5 \%$, i.e., comparisons are considered significant when $p<0.05$.

\section{RESULTS}

It was found that the mean age was $53.3 \pm 6.0$ years and all of them said that localized fat in the abdomen was what bothered them most and 75\% (3) of them had regular bowel and practiced physical activity sporadically. They had balanced diet, but without nutritional monitoring and $50 \%$ (2) of the patients was taking medications for treatment of other diseases, but do not interfere in the survey. So the participants were instructed to not follow nutritional guidelines and do not perform regular physical activity during their participation in the study to not influence the results. (Table 1).

As can be seen in Table 2, the initial and the final skinfold averaged, respectively, $47.5 \pm 6.5$ and $41.5 \pm 3.1$. The initial and the final weight averaged, respectively, $71.0 \pm 3.4$ and $70.8 \pm 4.6$.

Table 1. Distribution of the profile of evaluated women from Maringá-Paraná, Brazil.

\begin{tabular}{lcc}
\hline \multicolumn{1}{c}{ Variables } & n & $\%$ \\
\hline Age (Mean \pm Standard Deviation) & \multicolumn{2}{c}{$53.3 \pm 6.0$} \\
Aesthetic Complaint & \multicolumn{2}{c}{100.0} \\
$\begin{array}{l}\text { Localized Fat } \\
\text { Corporal Region }\end{array}$ & 4 & \\
Abdomen & \multicolumn{2}{c}{100.0} \\
\hline
\end{tabular}


The initial and the final Upper Abdominal Perimetry averaged, respectively, $83.9 \pm 6.4$ and $80.3 \pm 5.7$. The initial and the final Lower Abdominal Perimetry averaged, respectively, $97.7 \pm 4.3$ and $94.8 \pm 6$.7. The initial and the final Midline Abdominal Perimetry averaged, respectively,

Table 2. Distribution of mean, standard deviation of measurements reduction in women from Maringá - Paraná, Brazil.

\begin{tabular}{|c|c|c|c|c|}
\hline Variables & $n$ & Mean & $\begin{array}{l}\text { Reduction } \\
\text { Value }\end{array}$ & $\begin{array}{l}\text { Standard } \\
\text { Deviation }\end{array}$ \\
\hline \multicolumn{5}{|l|}{ Skinfold (cm) } \\
\hline Initial & 4 & 47.5 & & 6.5 \\
\hline Final & 4 & 41.5 & $6 \mathrm{~cm}$ & 3.1 \\
\hline \multicolumn{5}{|l|}{ Weight (kg) } \\
\hline Initial & 4 & 71.0 & & 3.4 \\
\hline Final & 4 & 70.8 & $0,2 \mathrm{~g}$ & 4.6 \\
\hline \multicolumn{5}{|l|}{$\begin{array}{l}\text { Upper Abdominal } \\
\text { Perimetry }(\mathrm{cm})\end{array}$} \\
\hline Initial & 4 & 83.9 & & 6.4 \\
\hline Final & 4 & 80.3 & $3,6 \mathrm{~cm}$ & 5.7 \\
\hline \multicolumn{5}{|l|}{$\begin{array}{l}\text { Lower Abdominal } \\
\text { Perimetry }(\mathrm{cm})\end{array}$} \\
\hline Initial & 4 & 97.7 & & 4.3 \\
\hline Final & 4 & 94.8 & $2,9 \mathrm{~cm}$ & 6.7 \\
\hline \multicolumn{5}{|c|}{$\begin{array}{l}\text { Midline Abdominal } \\
\text { Perimetry }(\mathrm{cm})\end{array}$} \\
\hline Initial & 4 & 92.9 & & 3.2 \\
\hline Final & 4 & 87.5 & $5,4 \mathrm{~cm}$ & 3.8 \\
\hline \multicolumn{5}{|l|}{$\begin{array}{l}\text { Triglycerides } \\
\text { (mg/dl) }\end{array}$} \\
\hline Initial & 4 & 193.8 & & 59.8 \\
\hline Final & 4 & 132.8 & $61 \mathrm{mg} / \mathrm{dl}$ & 52.7 \\
\hline \multicolumn{5}{|l|}{$\begin{array}{l}\text { Body mass index } \\
\left(\mathrm{kg} / \mathrm{m}^{2}\right)\end{array}$} \\
\hline Initial & 4 & 25.0 & & 1.6 \\
\hline Final & 4 & 24.8 & $0,2 \mathrm{~kg} / \mathrm{m}^{2}$ & 2.2 \\
\hline
\end{tabular}

$92.9 \pm 3.2$ and $87.5 \pm 3.8$. The initial and the final Triglycerides averaged, respectively, $193.8 \pm 59.8$ and $132.8 \pm 52.7$. The initial and the final Body mass index averaged, respectively, $25.0 \pm 1.6$ and $24.8 \pm 2.2$.

Checking the results it is observed that there was a reduction in the initial and final skinfold, the weight, the upper, lower and midline abdominal perimetry, the triglycerides and the body mass index, however none of these reductions was statistically significant when compared to subcutaneous and epicutaneous application of the equipment, highlighting the need for further studies with a larger sample (Table 3).

It is observed in Table 3, when comparing the types of applications using the Wilcoxon test, that it is not statistically significant, however can be seen a reduction in all the evaluations and the subcutaneous application displays more efficient in the treatment of localized adiposity.

\section{DISCUSSION}

During the twentieth century, the image of the health and beauty is shifted in relation to the concepts of the prior periods. The conquest of a beautiful and healthy body is understood as an individual objective to be attained through a deliberate exercise of self-control, involving willpower, restriction and constant surveillance. ${ }^{(14,15)}$ Studies discussed that, ${ }^{(16)}$ sociocultural theories of body image disorders refer to the influence of the established body ideals, expectations and experiences, as well as the etiology and maintenance of body image disorders.

Due to these constant stimuli and the search for a body accepted in society, one of the most obvious changes that occur with the increase in chronological age is the change in body size. Despite the high genetic component in weight, other factors such as diet, physical activity, psychosocial factors, diseases, among others, are involved in the changes during aging. (17) Localized fat or localized lipodystrophy consists of a change in the adipose cells characterized as a disorder of fat metabolism, affecting mainly hips, oblique, abdomen

Table 3. Comparative analysis of the before and after measures in the evaluated women from Maringá - Paraná, Brazil.

\begin{tabular}{|c|c|c|c|c|c|c|c|}
\hline \multirow[b]{2}{*}{ Variables } & \multicolumn{3}{|c|}{ Initial $(n=4)$} & \multicolumn{3}{|c|}{ Final $(n=4)$} & \multirow[b]{2}{*}{$p^{*}$} \\
\hline & Mean & Median & $\begin{array}{l}\text { Standard } \\
\text { Deviation }\end{array}$ & Mean & Median & $\begin{array}{l}\text { Standard } \\
\text { Deviation }\end{array}$ & \\
\hline Cutaneous Fold & 47.5 & 47.5 & 6.5 & 41.5 & 41.5 & 3.1 & 0.06789 \\
\hline Weight & 71.0 & 71.0 & 3.4 & 70.8 & 70.5 & 4.6 & 0.71500 \\
\hline Upper Abdominal Perimetry & 83.9 & 82.5 & 6.4 & 80.3 & 79.0 & 5.7 & 0.06789 \\
\hline Midline Abdominal Perimetry & 92.9 & 93.3 & 3.2 & 87.5 & 86.0 & 3.8 & 0.06789 \\
\hline Lower Abdominal Perimetry & 97.7 & 97.4 & 4.3 & 94.8 & 94.5 & 6.7 & 0.06789 \\
\hline Triglycerides & 193.8 & 187.0 & 59.8 & 132.8 & 120.0 & 52.7 & 0.06789 \\
\hline Body mass index & 25.0 & 25.0 & 1.6 & 24.8 & 25.0 & 2.2 & 0.59298 \\
\hline
\end{tabular}

* Wilcoxon paired test not significant considering the significance level of $5 \%(p<0.05)$. 
and thighs. ${ }^{(18,19,20)}$ This justified the execution of the research because all the participants had localized abdominal fat.

The excess of body fat and the hormonal action can lead to accumulation of fat tissue in certain parts of the body. In men, the most area affected is the abdomen and in women is the hip region. ${ }^{(9)}$ However, in this study, women complained mainly of localized fat in the abdomen and not fat located in the hip.

Data from this study are in agreement with the literature that any age women have on average a higher amount of total body fat than men, and the abdominal wall and the hip are the areas that have the greatest accumulation of this tissue. Adipose tissue is a form of connective tissue formed by cells known as adipocytes. They may be isolated or in small groups in the meshes of various connective tissues or grouped in large areas of the body such as the subcutaneous tissue. ${ }^{(9)}$

The electrolipophoresis is a technique for the treatment of adiposity and accumulation of localized fatty acids. In this technique applies a low-frequency microcurrent, which operates in adipocytes, producing malnutrition and favoring their subsequent elimination. The electrolipophoresis applies via needles implanted in adipose tissue or through electrodes on the skin surface. ${ }^{(9,11)}$ Electrical stimulation provides physiological effects such as an increase in blood flow, depolarization of cell membrane and lipolysis. ${ }^{(21)}$ These data were confirmed because all patients showed a decrease in adipose tissue, perimetry and skinfold, i.e., lipolysis occurs in plates and needles.

The electrolipophoresis technique allows reduction of adipose tissue, serum glycerol and subsequent increase in urinary glycerol. This increased metabolism enables the degradation of triglyceride and its subsequent use as an energy source. ${ }^{(10,21,22)}$

According to this research, it is clear that the use of the device resulted in decreased of local fat and blood triglyceride levels without nutritional intervention or physical activity. Other studies show that the lipase degrades triglycerides located inside the adipocyte, fatty acids and glycerol. Glycerol is transformed to glucose and is used as energy source and the fatty acid is metabolized in the liver to VLDL, $H D L$, and LDL-cholesterol. ${ }^{(23)}$ The neurohormonal effects of electrolipophoresis occurs by the action of the sympathetic nervous system that activates the release of adrenaline and noradrenaline via cyclic AMP. It stimulates the release of lipase, an enzyme that hydrolyze triglycerides in fatty acids and one glycerol molecule. ${ }^{(21,24)}$ The glycerol elimination in the urine does not occur in healthy individuals, this fact indicates activation of lipolysis which occurs due to hydrolysis of triglycerides. ${ }^{(12,21)}$

Studies have shown that the application of electrolipophoresis leads to the presence of significant amounts of glycerol in the urine, subsequent hours after treatment. According to some authors, this fact indicates activation of lipolysis that together with the aforementioned effects leads to a reduction in the adipose tissue, since the first session of therapy using this equipment. ${ }^{(11,12)}$

In this study was not evaluated glycerol dosage in the urine, but we observed that there was a reduction of blood triglyceride which can be explained by the activation of the ANS (autonomic nervous system) and the lipolysis of local and systemic triglyceride.

\section{CONCLUSION}

The observed results demonstrate that electrolipophoresis is effective in reducing localized abdominal adiposity. It was observed a reduction in the abdominal measurement and the rate of triglyceride in blood, due to the electrolipophoresis technique breaks triglycerides into fatty acids and glycerol wherein one is stored as energy source and the other is eliminate through urine.

However, although there was reduction in waist measurement and triglycerides in the blood, it was not statistically significant when compared to subcutaneous and epicutaneous administration of the equipment, because presented a $p>0.05$. Therefore, it is suggested that further studies with more participants and sessions are needed to confirm the results obtained in practice.

\section{AUTHOR'S CONTIBUTIONS:}

PHMB: Advisor

PM and ND: Implementation of instruments and equipment used in the research procedure

TMO: Research Development

\section{CONFLICT OF INTEREST:}

The authors declare that they have no conflicts of interest.

\section{AUTHOR DETAILS}

${ }^{2}$ Professor of the Biomedicine and Esthetics course, Unicesumar, Maringá (PR), Brazil

${ }^{3}$ Student of Esthetics and Cosmetics course, Uniceumar, Maringá (PR), Brazil ${ }^{4}$ Student of Esthetics and Cosmetics course, Uniceumar, Maringá (PR), Brazil

\section{REFERENCES}

1. Bayer R. Historia de la estetica. Trad. Jasmin Reuter. México: Fondo de Cultura Económica; 1965.

2. Hermann N. Ética e estética: a relação quase esquecida; 2005.

3. Witt JSGZ, Schneider AP. Nutrição Estética: valorização do corpo e da beleza através do cuidado nutricional. Instituto de Pesquisa Ensino e Gestão em Saúde. Ciênc. saúde coletiva [online]. 2011;16(9):3909-3916.

4. Braga PD, Molina MCB, Cade NV. Expectativas de adolescentes em relação a mudanças do perfil nutricional. Ciência \& Saúde Coletiva. 2007;12(5):1221-1228.

5. Costa RCA. O corpo na mídia: O discurso da saúde e a estética corporal contemporânea. Anais Colóquio de Moda. 2007;3ํo Colóquio de Moda(GT06):1-4.

6. Savoia MG. A imagem corporal. Rev Bras Psiquiatria; 2003;25(2):126-126.

7. Schmitz DS, Laurentino L. Estética facial e corporal: uma revisão bibliográfica. TCC (Graduação em Cosmetologia e Estética). 2010. Disponível em: http://Siaibib01.univali.br/pdf/Delourdes Schafascheck Schmitz, Lucia Laurentino.pdf. Acesso em 2014 (abr 9). 
8. Junqueira LC, Carneiro J. Histologia básica; 1999.

9. Guirro ECO, Guirro RRJ. Fisioterapia Dermato-Funcional: fundamentosrecursos-patologias; 2002.

10. Paula RM, Simões NP, Picheth G. Efeitos da eletrolipoforese nas concentrações séricas do glicerol do perfil lipídico. Fisioter Bras. 2007;3(Supl esp):5-9.

11. Borges FS. Dermato-funcional: modalidades terapêuticas nas disfunções estéticas; 2006.

12. Silva MT. Eletroterapia em estética corporal; 1997.

13. Azevedo CJD, Zanin EC, Tolentino TM, Cepeda CC, Busnardo VL. Estudo comparativo dos efeitos da eletrolipólise por acupontos e da eletrolipólise por acupontos associada ao trabalho aeróbico no tratamento da adiposidade abdominal grau I em indivíduos do sexo feminino com idade entre 18 e 25 anos. RUBS. 2008;1(2):64-71.

14. Andrade SS. Saúde e beleza do corpo feminino - algumas representações no Brasil do Século XX. Movimento. 2003;9(1):119-143.

15. Menezes JA. Ditadura da beleza. Epistemo Somática. 2006;3(2):265-267.

16. Heinberg LJ. Theories of body image disturbance: perceptual, developmental and sociocultural factor. In: Thompson JK, editor. Body image, eating disorders, and obesity: an integrative guide for assessment and treatment. Washington (DC): American Psychological Association. 1996:27-48
17. Fiatarone-singh MA. Body composition and weight control in older adults. In: LAMB, D. R.; MURRAY, R. Perspectives in exercise science and sports medicine: exercise, nutrition and weight control. Carmel: Cooper. 1998;11:243-288.

18. Gomes RK, Damazio MG. Cosmetologia: descomplicando os princípios ativos; 2009.

19. Duquia RP, Dumith SC, Reichert FF, Madruga SW, Duro LN, Menezes $\mathrm{AMB}$, et al. Epidemiologia das pregas cutâneas triciptal e subescapular elevadas em adolescentes. Cad. Saúde Pública. 2008;24(1):113-121.

20. Guirro ECO, Guirro RRJ. Fisioterapia Dermato-Funcional; 2004.

21. PARIENTI, I. J. Medicina estética; 2001.

22. Scorza FA, Figueiredo MM, Liao CO, Borges FS. Estudo comparativo dos efeitos da eletrolipólise com uso do tens modo burst e modo normal no tratamento de adiposidade localizada abdominal. Ensaios e ciência: Ciências biológicas, agrárias e da saúde. 2008;7(2):49-62.

23. Paula MR. Efeitos da eletrolipólise no perfil lipídico, glicêmico e hormonal de mulheres obesas. Dissertação (Mestrado em Engenharia Biomédica)Universidade Tecnológica Federal do Paraná. 2013. Disponível em: http:// repositorio.utfpr.edu.br/jspui/handle/1/745. Acesso em 2014 (Out 9).

24. Guyton AC, Hall JE. Tratado De Fisiologia Médica; 2002. 